\title{
СИСТЕМА ПРАВЛІННЯ В ІСЛАМСЬКІЙ РЕСПУБЛІЦІ ІРАН (1989-2019): ТИПОВА ЧИ АТИПОВА?
}

\author{
THE SYSTEM OF GOVERNMENT IN THE ISLAMIC REPUBLIC OF IRAN \\ (1989-2019): TYPICAL OR ATYPICAL ONE?
}

\author{
Осадчук І.Ю., \\ кандидат політичних наук, \\ доиент кафедри політології \\ Львівського національного університету імені Івана Франка
}

Інституційні й функціональні особливості систем правління в рамках республіканської фрорми державного правління в деяких країнах зумовлюють необхідність виділяти атипові президентські, атипові парламентські й атипові напівпрезидентські системи правління. Це пояснюється як особливостями формування і структури виконавчої влади, так і характером виконавчо-законодавчих відносин (насамперед у питанні відповідальності уряду). У цьому контексті актуальним є дослідження особливостей функціонування системи правління в Ісламській Республіці Іран у 1989-2019рр. Метою статті $є$ визначити особливості функціонування системи правління в Ісламській Республіці Іран у 1989-2019 рр. і з'ясувати її типовість чи атиповість. Для реалізації поставленої мети треба вирішити такі завдання: 1) визначити конституційні системи державного правління (президенталізм, парламентаризм, напівпрезиденталізм та асамблейно-незалежну систему правління) у рамках республіканської форми державного правління; 2) проаналізувати особливості формування й функціонування ключових інститутів влади (насамперед виконавчої та законодавчої) в Ісламській Республіці Іран у 1989-2019рр.; 3) на підставі специфіки формування і структури виконавчої влади, а також характеру виконавчо-законодавчих відносин визначити типовість чи атиповість системи правління в Ісламській Республіці Іран у 1989-2019рр.; 4) з'ясувати особливості політики президентів Ісламської Республіки Іран у 1989-2019 рр. і їхні взаємини з Лідером країни.

У статті розглянуто сучасну методику визначення систем державного правління в рамках республіканської форми державного правління. Проаналізовано особливості формування й функціонування ключових інститутів влади (насамперед виконавчої та законодавчої) в Ісламській Республіці Іран у 1989-2019 рр. Головними характеристиками системи правління в Ісламській Республіці Іран у 1989-2019 рр. виділено такі: 1) Лідер країни - глава держави (обирається експертами/Радою експертів); 2) президент обирається всенародно (на прямих виборах) на фріксований термін; 3) міністри є відповідальними перед парламентом; 4) дуалізація виконавчої влади, з одного боку, Лідером країни (як главою держави), а з іншого боку, президентом (як главою уряду) й урядом/урядовим кабінетом. На підставі цих характеристик систему правління в Ісламській Республіці Іран у 1989-2019 рр. визначено як атипову, яка при цьому не є атиповою президентською, атиповою парламентською, атиповою напівпрезидентською чи атиповою асамблейно-незалежною системою правління. З'ясовано особливості політики президентів Ісламської Республіки Іран у 1989-2019 рр. і їхні взаємини з Лідером країни. Доведено, що будь-яка спроба президентів розширити свої повноваження була заблокована Лідером країни за допомогою підконтрольних йому політичних інститутів (зокрема за допомогою Ради з визначення державної доцільності). Крім того, реформи, ініційовані президентами в Ісламській Республіці Іран у 1989-2019рр., які б сприяли суттєвій трансорормації політичного режиму, також були заблоковані Лідером країни А. Хаменеї та консервативним табором правлячої еліти.

Ключові слова: система державного правління, атипова система правління, Лідер країни, інститут президентства, урядовий кабінет, Ісламська консультативна рада, Рада експертів, Ісламська Республіка Іран.

The institutional and functional features of systems of government within the republican form of government make it necessary to single out atypical presidential, atypical parliamentary and atypical semi-presidential systems of government in some countries. This is due both to the peculiarities of formation and structure of the executive, as well as to the nature of executive-legislative interrelations (first of all, in the matter of governmental cabinet responsibility). Therefore, the study of the peculiarities of system of government's functioning in the Islamic Republic of Iran in 1989-2019 is relevant in this context. The purpose of the article is to determine the features of system of government's functioning in the Islamic Republic of Iran in 1989-2019 and to find out its typicality or atypicality. To achieve this purpose, the author had to solve the following tasks: 1) to define constitutional systems of government (presidentialism, parliamentarism, semi-presidentialism and assembly-independent system of government) within the framework of republican form of government; 2) to analyze the peculiarities of formation and functioning of key institutions (first of all, the executive and legislative power) in the Islamic Republic of Iran in 1989-2019; 3) to determine the system of government's typicality or atypicality in the Islamic Republic of Iran in 1989-2019, in particular on the basis of the specifics of formation and structure of the executive and the nature of executive-legislative interrelations; 4 ) to find out the peculiarities of the President's policy and its relations with the Leader's institution in the Islamic Republic of Iran in 1989-2019.

As a consequence, the article discusses the modern technique of defining systems of government within the framework of republican form of government. The author analyzed the peculiarities of formation and functioning of key institutions (first of all, the executive and legislative power) in the Islamic Republic of Iran in 1989-2019. It was found that the system of government in the Islamic Republic of Iran in 1989-2019 was characterized by certain significant parameters, in particular: 1) The Leader elected by the experts/the Assembly of Experts is the head of state; 2) the president is elected popularly and directly for a fixed term; 3 ) ministers are responsible to parliament; 4) the system of government is characterized with the executive dualism between the Leader (as the head of state) and the President (as the head of government) 
and governmental cabinet. Based on these characteristics, the system of government in the Islamic Republic of Iran in 1989-2019 was defined as an atypical one, but not atypical presidential, atypical parliamentary, atypical semi-presidential or atypical assembly-independent one. This conclusion was confirmed on the basis of the particularities of the President's policy and its relations with the Leader's institution in the Islamic Republic of Iran in 1989-2019. The study proved that any presidential attempt to expand the powers was blocked by the Leader through political institutions under his control (in particular, through the Nation's Exigency Council). In addition, the reforms initiated by presidents of the Islamic Republic of Iran in 1989-2019, which could have helped significantly transform the political regime, were also blocked by the Leader Ali Khamenei and the conservative camp of the ruling elite.

Key words: system of government, atypical system of government, Leader, institution of presidency, governmental cabinet, Islamic Consultative Assembly, Assembly of Experts, Islamic Republic of Iran.

Постановка проблеми. Досвід функціонування систем правління в рамках республіканської форми державного правління в деяких країнах зумовлює необхідність виділяти атипові президентські, атипові парламентські й атипові напівпрезидентські системи правління. Це пояснюється як особливостями формування і структури виконавчої влади, так і характером виконавчо-законодавчих відносин (насамперед у питанні відповідальності уряду). У 1989 р. в Ісламській Республіці Іран після смерті Лідера країни, лідера Ісламської революції аятоли Р. Хомейні Рада експертів обрала главою держави А. Хаменеї. Крім того, у 1989 р. до Конституції 1979 р. внесено зміни (зокрема скасовано посаду прем'єр-міністра). У цьому контексті актуальним є дослідження особливостей функціонування системи правління в Ісламській Республіці Іран у 1989-2019 рр.

Аналіз останніх досліджень і публікацій. Атипові республіканські системи правління або окремі аспекти політичного процесу та міжінституційних відносин, які прямо чи опосередковано вказують на атиповість систем правління в рамках республіканської форми державного правління, проаналізовано в працях таких авторів, як О. Зазнаєв [1], I. Осадчук [2-4], В. Литвин [2] тощо. Інституційні й функціональні особливості системи правління в Ісламській Республіці Іран проаналізовано в працях таких авторів, як О. Дунаєва [5; 6], В. Іваненко [7], Н. Мамедова [8], Н. Мартиненко [9], Х. Чехабі [10], А. Шіразі [10] та інші.

Формулювання цілей статті (постановка завдання). Мета статті - визначити особливості функціонування системи правління в Ісламській Республіці Іран у 1989-2019 pр. і з'ясувати їі типовість чи атиповість. Для реалізації поставленої мети треба вирішити такі завдання: 1) визначити конституційні системи державного правління (президенталізм, парламентаризм, напівпрезиденталізм та асамблейно-незалежну систему правління) у рамках республіканської форми державного правління; 2) проаналізувати особливості формування й функціонування ключових інститутів влади (насамперед виконавчої та законодавчої) в Ісламській Республіці Іран у 1989-2019 рр.; 3) на підставі специфіки формування і структури виконавчої влади, а також характеру виконавчо-законодавчих відносин визначити типовість чи атипо- вість системи правління в Ісламській Республіці Іран у 1989-2019 рp.; 4) з'ясувати особливості політики президентів Ісламської Республіки Іран у 1989-2019 рр. і їхні взаємини з Лідером країни.

Виклад основного матеріалу дослідження. Теоретико-методологічною основою наукового дослідження вибрано неоінституціоналізм і його варіативні типи й парадигми.

Однією 3 найапробованіших методик визначення типових конституційних і політичних систем державного правління в рамках республіканської форми державного правління є методика Р. Елгі [11]. У дослідженні ми використовуємо модифікацію типології систем державного правління Р. Елгі, розроблену українським дослідником В. Литвином, який визначає: а) президенталізм (президентську систему правління) як конституційну (i/ чи політичну) систему республіканської форми державного правління (спрощено систему державного правління), якій властива посада всенародно (прямо/опосередковано) обраного на фіксований термін президента й інституту кабінету/адміністрації президента (навіть, можливо, прем'єр-міністра), члени яких колективно відповідальні виключно перед президентом (разом із цим члени кабінету чи адміністрації президента можуть бути й індивідуально відповідальними перед парламентом/ провідною палатою парламенту (легіслатурою), однак це не має дефінітивного впливу та значення на структурування системи державного правління); б) парламентаризм (парламентську систему правління) як конституційну (i/чи політичну) систему республіканської форми державного правління (спрощено систему державного правління), за якої президент отримує свої повноваження на підставі непрямого (невсенародного) вибору (наприклад, у легіслатурі), а прем'єр-міністр й урядовий кабінет колективно відповідальні виключно перед легіслатурою (разом із цим члени уряду, крім прем'єрміністра, можуть бути індивідуально відповідальними й перед президентом і легіслатурою, однак це не має дефінітивного значення й впливу на структурування системи державного правління); в) напівпрезиденталізм (напівпрезидентську систему правління) як конституційну (i/чи політичну) систему республіканської форми державного правління (спрощено систему державного правління), якій властиві посада всенародно (прямо/опосередковано) обраного на фіксований термін президента, 
a також інститут прем'єр-міністра й урядового кабінету, які обов'язково колективно відповідальні хоча б перед легіслатурою (разом із цим прем'єрміністр та урядовий кабінет можуть бути водночас колективно відповідальними й перед парламентом, і перед главою держави; більше того, міністри урядового кабінету можуть бути індивідуально відповідальними перед парламентом i/чи президентом, але це не має жодного дефінітивного значення та впливу на структурування системи державного правління), а також притаманний процес суміщення або дуалізації виконавчої влади, 3 одного боку, президентом (обов'язково як главою держави), а 3 іншого боку, прем'єр-міністром (обов'язково як главою уряду) та урядом/урядовим кабінетом $[12$, c. $5 ; 13$, с. 7]. Незалежно від природи та процесуальної логіки парламентського вотуму недовіри уряду й/чи прем'єр-міністру напівпрезидентською позиціонується та система державного правління, у якій існує «безперервна» обов'язкова колективна відповідальність уряду та прем'єр-міністра перед легіслатурою чи, інакше кажучи, у якій легіслатура володіє ініціативою ставити питання про колективну відповідальність уряду. Натомість усі інші/ додаткові уточнення та атрибути є тільки допоміжними правилами класифікації систем правління, які варто застосовувати тільки в типологізації напівпрезиденталізму [12, с. 80]. Указану модифікацію типології систем державного правління в рамках республіканської форми державного правління ми доповнюємо асамблейно-незалежною системою правління. М. Шугарт і Дж. Кері, а також О. Зазнаєв визначають асамблейно-незалежну систему правління як систему правління, для якої характерні такі ознаки: 1) невсенародні вибори президента; 2) уряд не несе відповідальності перед парламентом $[1$, c. $55 ; 14$, c. 26$]$.

Проаналізуймо особливості формування та функціонування ключових політичних інститутів, а також виконавчо-законодавчі відносини в Ісламській Республіці Іран у 1989-2019 рр. Лідер країни - найвища посадова особа в країні (ст. 113 Конституції IPI) $[15 ; 16]$. Лідер країни обирається експертами/Радою експертів. Рада експертів (складається з 86 членів) обирається на 8 років шляхом загальних прямих виборів (вибори відбулися в 1982, 1990, 1998, 2006 рр., згодом термін повноважень продовжено до 10 років, тому останні вибори відбулися у 2016 р.). Більшість експертів, які обираються до Ради, - представники вищого духовенства [8, с. 155]. Вимоги, що висуваються до Лідера країни, такі: 1) необхідна наукова компетентність для винесення фетв із різних питань мусульманського права; 2) справедливість і побожність для управління ісламською нацією; 3) правильний політичний і соціальний світогляд, розсудливість, сміливість, організаційні здібності й сила, достатня для управління. Якщо декілька осіб відповідають вищевказаним вимогам, то перевага надається тому, хто володіє сильнішим богословським і політичним світоглядом (ст. 109) $[15 ; 16]$. Якщо експерти визнають одного 3 кандидатів найбільш компетентним у питаннях мусульманського права або в політичних і соціальних проблемах, а також уважатимуть його визнаним усім народом або таким, який відповідає вимогам, передбаченими ст. 109, то його вибирають Лідером країни. Обраний експертами Лідер країни $\epsilon$ ватажком мусульман і несе за це відповідальність (ст. 107 Конституції IPI) [15; 16].

Права й обов'язки Лідера країни, відповідно до ст. 110 Конституції IPI, такі: 1) визначення загальної політики держави Ісламської Республіки Іран після консультацій із Радою $з$ визначення державної доцільності; 2) контроль за виконанням загальної політичної лінії держави; 3) прийняття рішення про проведення всенародного референдуму; 4) верховне командування Збройними силами; 5) оголошення війни і миру та мобілізації; 6) призначення й відправлення у відставку таких осіб і прийняття їхньої відставки: а) факіхів Ради 3 охорони конституції; б) глави судової влади; в) голови телерадіомовної Організації «Голос та образ Ісламської Республіки Іран»; г) начальника об'єднаного штабу; д) головнокомандувача Корпусу вартових Ісламської Революції; е) головнокомандувачів Збройними силами та внутрішніми військами; 7) вирішення спорів і впорядкування відносин між трьома гілками влади; 8) подолання проблем держави за допомогою Ради 3 визначення державної доцільності; 9) підписання указу про призначення президента, обраного народом (компетентність кандидатів на посаду президента щодо їх відповідності вимогам, закріпленим у Конституції, має бути підтверджена до виборів Радою з охорони Конституції й схвалена Лідером країни на першому етапі); 10) звільнення з посади президента 3 урахуванням інтересів країни згідно 3 висновком, винесеним Верховним судом щодо порушення президентом своїх законних повноважень або відповідно до рішення Меджлісу ісламської ради про невідповідність президента займаній посаді; 11) амністія або пом'якшення покарання особам, щодо яких винесено вирок, у рамках ісламських норм і за пропозицією глави судової влади $[15 ; 16]$.

Якщо Лідер країни буде не в змозі виконувати свої законні обов'язки, або втратить якості, зазначені в ст. ст. 5 і 109, або якщо стане відомо, що він із самого початку не відповідав цим вимогам, то він усувається 3 посади. Рішення із цього приводу приймається експертами/Радою експертів (ст. 111 Конституції IPI) $[15 ; 16]$.

Зазначимо, що в Конституції в редакції 1979 р. Лідер країни був проголошений пожиттєвим рахбаром (керівник шиїтської громади) i марджа 
ат-таклід (релігійний наставник) [8, с. 155]. Ф. Фархі у функціонуванні інституту Лідера країни вбачає дві проблеми для майбутнього IPI. Перша проблема полягає в тому, що Лідер країни на практиці фактично довічно перебуває на своїй посаді, а друга проблема - у тому, що перебування однієї й тієї ж особи на цій посаді виявилося засобом узурпації влади [17]. Лідер країни контролює низку фінансових потоків: доходи ісламських фондів, ісламські податки тощо [8, с. 156].

Виконавча влада здійснюється президентом $і$ міністрами в усіх випадках, крім тих, які Конституцією безпосередньо зараховані до компетенції Лідера країни (ст. 60 Конституції IPI) [15; 16]. Президент $є$ другою найвищою посадовою особою країни. Президент відповідає за виконання Конституції й керує виконавчою владою в усіх сфеpax, крім тих, що зараховані до компетенції Лідера країни (ст. 113 Конституції IPI) [15; 16]. Президент обирається на 4 роки на загальних прямих виборах, причому може обиратися тільки на два терміни поспіль (ст. 114 Конституції IPI) $[15 ; 16]$.

Президент керує Радою міністрів (урядом), контролює іiі діяльність і своїми рішеннями узгоджує діяльність уряду й усіх міністрів, а також визначає програму й напрями діяльності уряду та виконує закони. У разі виникнення розбіжностей або втручання в законні повноваження урядових органів тоді, коли немає необхідності в тлумаченні та зміні закону, рішення Ради міністрів, прийняте за пропозицією президента, $є$ обов'язковим для виконання. Президент відповідає за дії Ради міністрів перед Меджлісом ісламської ради/Ісламською консультативною радою (парламентом) (ст. 134 Конституції IPI) [15; 16]. Президент може мати заступників для виконання своїх повноважень, передбачених законом. Перший віце-президент за погодженням із президентом спрямовує діяльність Ради міністрів та інших заступників президента (ст. 124 Конституції IPI) [15; 16].

Якщо Меджліс ісламської ради висловлює вотум недовіри Раді міністрів (усім міністрам, за винятком президента), то міністри йдуть у відставку (ст. 89 Конституції IPI) [15; 16]. Якщо як мінімум третина депутатів Меджлісу ісламської ради подає інтерпеляцію до президента з приводу керівництва виконавчою владою й управління справами країни, то президент повинен протягом місяця з'явитися в Меджліс і дати вичерпні роз'яснення із цього приводу. Якщо дві третіх від загальної кількості депутатів проголосують за невідповідність президента займаній посаді (висловлять вотум недовіри), про це буде повідомлено Лідеру країни (ст. 89) [15; 16]. Своєю чергою, Лідер країни звільняє з посади президента 3 урахуванням інтересів країни згідно з висновком, винесеним Верховним судом, щодо порушення президентом своїх законних повноважень або відповідно до рішення Меджлісу ісламської ради про невідповідність президента займаній посаді (п. 10 ст. 110 Конституції IPI) [15; 16].

3 метою захисту норм ісламу й запобігання протиріччям Конституції з постановами Меджлісу ісламської ради створюється Рада 3 охорони Конституції/Рада вартових Конституції/Наглядова рада в такому складі: 1) 6 осіб - богословів (факіхів), які призначаються Лідером країни; 2) 6 мусульманських правознавців/юристів, яких представляє Меджлісу ісламської ради глава судової влади для подальшого обрання (ст. 91 Конституції IPI). Без висновків Ради з охорони Конституції рішення Меджлісу ісламської ради не мають законної сили, крім випадків затвердження мандатів депутатів і виборів 6 юристів до Ради 3 охорони Конституції (ст. 93 Конституції IPI) $[15 ; 16]$. Усі рішення Меджлісу ісламської ради повинні відправлятися до Ради 3 охорони Конституції, яка впродовж максимум 10 днів 3 дня отримання документів розглядає їх з погляду відповідності ісламським нормам і Конституції. Якщо Рада 3 охорони Конституції встановить, що рішення Меджлісу ісламської ради суперечать зазначеним нормам, то Рада 3 охорони Конституції направляє їх назад у Меджліс для повторного розгляду. В іншому випадку рішення Меджлісу вступають у силу (ст. 94 Конституції IPI) $[15 ; 16]$. Якщо Рада 3 охорони Конституції визнає 10-денний термін недостатнім для розгляду рішень Меджлісу і прийняття остаточного рішення, то Рада може із зазначенням причин відтермінування просити в Меджлісу ще 10 днів для завершення розгляду. Рада 3 охорони Конституції здійснює контроль за виборами Ради експертів, президента, Меджлісу ісламської ради, зверненням до громадської думки та референдумом (ст. 99 Конституції IPI) [15; 16].

У тих випадках, коли Рада 3 охорони Конституції визнає постанову Меджлісу ісламської ради такою, що суперечить нормам шаріату або Конституції, а Меджліс з урахуванням державної доцільності не погодиться 3 цим рішенням Ради 3 охорони Конституції, а також для консультації 3 питань, які передаються їй на розгляд Лідером країни й для виконання інших функцій, зазначених у Конституції, за вказівкою Лідера країни створюється Рада $з$ визначення державної доцільності. Постійні й тимчасові члени Ради призначаються Лідером країни. Регламент роботи Ради розробляється і приймається самими іiі членами й затверджується Лідером країни (ст. 112 Конституціï IPI) $[15 ; 16]$.

Корпус вартових Ісламської Революції (далі KВIP), який створений у перші дні перемоги революції 1979 р., зберігається для забезпечення охорони революції (ст. 150 Конституції IPI) $[15 ; 16]$. На КВІР покладено такі завдання армійської, жандармсько-поліцейської та релігійно-іслам- 
ської специфіки, а також завдання економічного характеру: 1) забезпечення внутрішньої безпеки ісламського режиму в Ірані шляхом боротьби 3 опозицією, запобігання антиурядовим виступам населення; 2) здійснення контролю за діяльністю політичних, громадських і неурядових організацій, приватних компаній і фірм; 3) відбиття разом 3 армією іноземної агресії; 4) ведення зовнішньої розвідки й контррозвідки; 5) запобігання проникненню в країну «західної ідеології й культури»; 6) підготовка та керівництво силами опору «Басідж»; 7) контроль за суворим дотриманням усіма громадянами ісламських норм життя $\mathrm{i}$ моралі; 8) утілення в життя концепції «експорту ісламської революції»; 9) боротьба з наркобізнесом і бандитизмом; 10) участь в охороні державного кордону; 11) участь у здійсненні великомасштабних державних проектів у рамках відновлення та розвитку економіки [18, с. 94]. Міжнародні фінансово-економічні санкції, уведені проти IPI у зв'язку з їі ядерною програмою у 2006 р., й особливо односторонні санкції США, Свросоюзу та багатьох інших країн від 2011 р. створили умови для ще більшого входження КВІР в економіку країни. В умовах, коли можливості іноземних інвесторів виявилися обмежені, керівництву IPI довелося робити ставку на внутрішні сили. В умовах незначних можливостей (як фінансових, так і технічних) приватного сектора організації підконтрольні KBIP виявилися найбільш прийнятними претендентами на заміну іноземних корпорацій. Корпусу були надані контракти з будівництва метро, право на розробку газових родовищ, будівництво газопроводів тощо [18, с. 104].

Отже, ключовими характеристиками системи правління в Ісламській Республіці Іран у 19892019 рр. є такі: 1) Лідер країни - глава держави (обирається експертами/Радою експертів); 2) президент обирається всенародно (на прямих виборах) на фіксований термін; 3) міністри є відповідальними перед парламентом; 4) дуалізація виконавчої влади, з одного боку, Лідером країни (як главою держави), а з іншого боку, президентом (як главою уряду) та урядом/урядовим кабінетом. На підставі цих характеристик систему правління в Ісламській Республіці Іран у 1989-2019 рр. визначено як атипову, яка не є атиповою президентською, атиповою парламентською, атиповою напівпрезидентською чи атиповою асамблейно-незалежною системою правління.

Розглянемо особливості політики президентів IPI в 1989-2019 pp. і їхні взаємини з Лідером країни. Президент А.А. Хашемі Рафсанджані (1989-1997) відмовився від нав'язаного іраноіракською війною (1980-1988) курсу із централізованого управління економікою на користь ліберальних реформ в економічній сфері [9, с. 75]. Ці реформи передбачали лібералізацію внутрішніх цін (насамперед на продукти сільського господарства), валютного обміну й зовнішньої торгівлі; часткову приватизацію держсектора; поступову відмову від цінового субсидування товарів продовольчого попиту й заміну субсидій адресною допомогою тощо [19, с. 427]. Перший п'ятирічний план, незважаючи на конституційний принцип, що забороняв іноземне втручання в економіку країни (п. 8 ст. 43 Конституції IPI), передбачав залучення іноземних кредитів, зокрема, у формі капіталу. У цьому плані передбачалося користування кредитами на умовах «buy-back»: розрахунки Ірану 3 зарубіжними інвесторами могли проводитися шляхом прямих поставок продукції третій стороні іноземному покупцю, який, своєю чергою, брав на себе обов'язок здійснити гарантовані платежі інвестору. Під час другого терміну президентства А.А. Хашемі Рафсанджані намагався посилити президентську владу, на обговорення Меджлісу було подано проект про скасування обмежень щодо кількості термінів перебування на посаді президента. Ці спроби провалилися, оскільки водночас відбувалося підвищення авторитету А. Хаменеї як духовного лідера [20, с. 110-118].

Президентство М. Хатамі (1997-2005) характеризувалося певною лібералізацію в культурній і політичній сферах. При цьому в економіці лібералізація була більш стриманою, на відміну від економічної політики президента А.А. Хашемі Рафсанджані, особливо в питаннях зовнішньоекономічного співробітництва і приватизації [21, с. 230]. У 1999 р. Центробанк Ірану прийняв постанову, що дозволила створення банків і страхових компаній зі $100 \%$ іноземною участю без будь-яких обмежень їхньої діяльності в затверджених згідно із законом 1993 р. вільних комерційно-індустріальних зонах. У липні 2002 р. в Ірані були випущені перші в історії Ісламської Республіки єврооблігації терміном на 5 років на суму 500 млн. євро [22, с. 106].

Президент М. Хатамі запропонував концепцію «Іслам і громадянське суспільство», яка передбачала розвиток країни на основі традицій, притаманних іранському суспільству. Отже, зроблена спроба в рамках громадянського суспільства створити соціальну базу для здійснення подальшої модернізації. М. Хатамі вважав, що основною проблемою іранського суспільства $є$ «слабкість релігійного інтелектуалізму», яку він убачав у відсутності розуміння сучасних проблем [23, с. 152-178, 232-233]. До прихильників М. Хатамі входили представники різних соціальних груп: інтелігенції, студентської молоді, деяких підприємницьких і військових кіл, чиновництва й, що особливо показово, духовенства. Крім того, на підтримку М. Хатамі активно виступили глави місцевих адміністрацій (генерал-губернатори) [24, с. 173]. У 1999 р були проведені вибори в міські й сільські ради першого скликання. У великих містах 
більшість депутатських місць зайняли прихильники демократизації ісламського ладу. Стратегія М. Хатамі, його спрямованість у рамках обраного курсу на зміцнення громадянського суспільства, розширення прав іранців, широка соціальна база реформаторського руху викликали позитивний відгук міжнародного співтовариства. У Західній Європі заговорили про необхідність підтримати іранського президента, заохочувати його зусилля. Знаковою в цьому контексті подією було відновлення ірано-британських дипломатичних відносин. У мусульманському світі, передусім в арабських країнах, М. Хатамі був сприйнятий як політичний діяч компромісного характеру, здатний до пошуку шляхів взаємоприйнятної зовнішньополітичної взаємодії [24, с. 173-174].

Президент М. Хатамі, завдяки парламентській більшості (за результатами парламентських виборів 2000 р. партія Ісламський фронт участі Ірану зайняла 189 місць із 290 [25]; фракція реформаторів становила 195 місць із 290 [26]) ініціював демократичні реформи в політичній сфері, однак зазнав протидії з боку Лідера країни й консервативного табору. Серед ініційованих реформ варто виділити такі: 1) законопроект про свободу ЗМІ. У серпні 2000 р. Лідер країни А. Хаменеї заблокував проект закону про свободу 3МI, аргументувавши це тим, що в разі його прийняття вороги ісламу отримають можливість активно просувати свої ідеї в ЗМІ; 2) законопроекти, що розширювали б повноваження президента (він наділявся правом контролю над виконанням конституційних норм за допомогою ветування будь-яких рішень, що суперечать Конституції, а державні установи ставали підзвітні президенту в питаннях порушення норм Основного Закону) й обмежували б роль Ради 3 охорони Конституції/Ради вартових Конституції в електоральному процесі [9, с. 76-77]; 3) законопроект щодо запровадження процедури додаткового розгляду спеціальним арбітражним судом рішень Ради 3 охорони Конституції/Ради вартових Конституції з правом їх відхилення [24, с. 175]. Усі ці законопроекти були відхилені Радою з визначення державної доцільності.

У рамках кампанії щодо боротьби з корупцією, яка розгорнулася у 2002 р., звинувачення були висунуті проти представників апарату уряду і президента. До кримінальної відповідальності притягнули радника президента А. Абаді. Його провина полягала в тому, що він брав участь в організації громадського опитування з проблеми відновлення ірано-американських відносин [24, с. 176].

Лідер країни А. Хаменеї був особливо політично активний у період президентства М. Ахмадінежада (2005-2013), фактично привівши його до влади $[8$, с. 156]. За перші чотири роки президентства М. Ахмадінежада КВІР набув величезного політичного й економічного впливу в країні і став успішним конкурентом верховному духовенству. КВІР, вихідці з якого становили приблизно одну третю від загального складу Меджлісу [27], отримав можливість призначати міністрів, губернаторів та інших держчиновників вищого й середнього рівнів. За сприяння М. Ахмадінежада КВІР узяв під контроль дві третіх економіки країни [28]. Представники КВІР очолили також кілька найбільших іранських ісламських фондів. КВIP витіснив фонди, що належали аятолам, із багатьох прибуткових проектів, що призвело до підриву економічної незалежності вищого духовенства [7, с. 75-76]. В економічній сфері М. Ахмадінежад уже в кінці 2006 р. приступив до виконання програми, що передбачала «справедливий і рівномірний» розподіл серед іранського населення доходів, отриманих від нафтового експорту [29]. Це завдало серйозного удару по іранській економіці. Згідно з даними станом на 2008 р., 20\% населення зосередило в руках 70\% фінансів країни, тоді як $60 \%$ населення перебувало на межі бідності або за межею бідності [30].

За результатами президентських виборів 2009 р., М. Ахмадінежад обраний на другий термін. М. Мусаві (головний кандидат від «реформаторів», опонент М. Ахмадінежада на виборах 2009 р.) заявив про фальсифікації результатів і закликав своїх виборців вийти на вулицю. Протестний «Зелений рух» очолили М. Мусаві, експрезидент IPI М. Хатамі та М. Каррубі (голова Меджлісу ісламської ради/Ісламської консультативної ради в 1989-1992 і 2000-2004рр.). Масові виступи «зелених» проходили майже в усіх великих містах Республіки. Упродовж року «Зелений рух» було придушено поліцейськими силами, масовими арештами учасників демонстрацій, особливо студентів [7, с. 78]. У 2009-2010 pp. на демонстраціях також лунали гасла проти диктатури Лідера країни А. Хаменеї [31, с. 182]. Невдоволення частини вищого духовенства політикою М. Ахмадінежада призвело до того, що на підтримку опозиції виступила частина духовенства Ірану. Лідер країни А. Хаменеї, його оточення i представники в провінціях підтримали президента. Голова Ради з визначення державної доцільності А.А. Хашемі-Рафсанджані, який підтримав «реформаторів», був змушений піти 3 іншої ключової посади - голови Ради експертів, що значно послабило позиції реформаторського табору [7, с. 79].

Як зазначає В. Іваненко, після перемоги на вибоpax 2009 p. М. Ахмадінежад став демонструвати свою незалежність від Лідера країни А. Хаменеї. Своєю чергою, А. Хаменеї продовжував використовувати політичні «противаги» М. Ахмадінежаду, такі як клан Ларіджані, представники якого, брати Алі й Садек, очолили, відповідно, законодавчу й судову владу IPI. А. Ларіджані вдалося сформувати в Меджлісі впливову антипрезидент- 
ську групу депутатів, яка протидіяла економічним і кадровим ініціативам М. Ахмадінежада [7, с. 79]. У 2011 р. на тлі посилення протиріч між М. Ахмадінежадом та А. Хаменеї (відкрита конфронтація президента з Лідером країни, розбіжності в кадрових питаннях, звинувачення М. Ахмадінежада у волюнтаризмі тощо), а також між законодавчою та виконавчою гілками влади в політичній системі 3'явився новий інститут, який був покликаний урегулювати розбіжності між основними інститутами державної влади, - Вища комісія з вирішення протиріч і врегулювання відносин між трьома гілками влади. Однак посилення розколу всередині політичних еліт, жорстке суперництво виконавчої й законодавчої влади призвели до поглиблення внутрішньополітичної кризи, тому діяльність комісії була зведена нанівець [9, с. 81].

За результатами президентських виборів 2013 р., перемогу здобув Х. Рухані, який визначив три принципи свого курсу: справедливість, законність і поміркованість [32]. Як зазначає Н. Мартиненко, перемога X. Рухані на президентських виборах швидше за все була результатом усвідомленої політики духовного лідера А. Хаменеї як відповідь на вимоги значної частини населення щодо лібералізації політики IPI в усіх сферах [9, с. 82]. Серед особливостей політики президента X. Рухані варто виділити такі: 1) деполітизація вищих навчальних закладів і зниження рівня впливу держави на навчальний процес (наприклад, ректори вищих навчальних закладів обиралися науковим співтовариством і затверджувалися міністерством і Вищою радою культурної революції); 2) уперше було розроблено проект «Хартії прав громадян» (26 листопада 2013 р. проект було опубліковано), а також порушено питання про права національних і релігійних меншин. При президенті вперше запроваджено посаду спеціального помічника у справах національних меншин і конфесій [9, с. 82-83]; 3) Х. Рухані заявив про необхідність забезпечення прав жінок. Президент виступив проти впровадження хіджабу силовими методами й заявив про необхідність розробити законопроект, що забороняє поліції моралі переслідувати жінок, які порушують суворий ісламський дрес-код [33]. Варто згадати також про призначення М. Афхам прес-секретарем Міністерства закордонних справ Ірану (вперше посаду такого рівня зайняла жінка [34]). Кілька жінок були призначені на посади заступників міністрів та особистих радників президента, а М. Ебтекар стала віце-президентом IPI [9, с. 83].
Професор історії Університету Джорджа Мейсона (США) Ш. Бахаш зазначає, що президент Х. Рухані, безсумнівно, не контролює ні силові структури, ні судову владу, які, рішуче налаштовані завадити його наміру зробити політичну систему більш відкритою. Правляча еліта, яку часто називають прихильниками жорсткої лінії або консерваторами, контролює основні інструменти влади: силові відомства, розвідувальне управління, збройні сили й поліцію, судову систему, Раду з охорони Конституціі/Раду вартових Конституції та Раду експертів. Із ними пов'язана економічна еліта, яка колосально розбагатіла на державних контрактах і квазімонополіях на імпорт основних товарів. Ці еліти будуть чинити опір будь-якій загрозі посягання на їхню владу та привілеї. Вони також побоюються, імовірно, не без вагомих на те підстав, що будь-яка серйозна реформа (політична, економічна чи соціальна), сприятиме змінам, які поставлять під загрозу всю чинну систему [35].

Висновки та перспективи подальших розвідок у цьому напрямі. Головними характеристиками системи правління в Ісламській Республіці Іран у 1989-2019 рр. виділено такі: 1) Лідер країни - глава держави (обирається експертами/ Радою експертів); 2) президент обирається всенародно (на прямих виборах) на фіксований термін; 3) міністри є відповідальними перед парламентом; 4) дуалізація виконавчої влади, з одного боку, Лідером країни (як главою держави), а 3 іншого боку, президентом (як главою уряду) та урядом/урядовим кабінетом. На підставі цих характеристик систему правління в Ісламській Республіці Іран у 1989-2019 рр. визначено як атипову, яка при цьому не є атиповою президентською, атиповою парламентською, атиповою напівпрезидентською чи атиповою асамблейно-незалежною системою правління. Доведено, що будь-яка спроба президентів розширити свої повноваження була заблокована Лідером країни за допомогою підконтрольних йому політичних інститутів (зокрема за допомогою Ради з визначення державної доцільності). Крім того, реформи, ініційовані президентами в Ісламській Республіці Іран у 1989-2019 рр., які б сприяли суттєвій трансформації політичного режиму, також були заблоковані Лідером країни А. Хаменеї та консервативним табором правлячої еліти. У подальших дослідженнях проаналізуємо особливості функціонування системи правління в Ісламській Республіці Іран у 1979-1989 pp. 


\section{СПИСОК ВИКОРИСТАНИХ ДЖЕРЕЛ:}

1. Зазнаев О. Атипичные президентские и полупрезидентские системы. Ученые записки Казанского государственного университета. Серия «Гуманитарные науки». 2005. Т. 147. Кн. 1. С. 54-69.

2. Осадчук І., Литвин В. Атиповість напівпрезидентських систем державного правління в пострадянських країнах: контекст вотумів недовіри урядам. Politicus. 2018. Вип. 3. С. 49-57.

3. Осадчук І. Атиповість президентської системи правління в Болівії (1985-1993рр.). Вісник Львівського університету. Серія «Філософрсько-політологічні студії». 2018. Вип. 20. С. 187-192.

4. Осадчук І. Прямі вибори прем'єр-міністра як індикатор атипової парламентської системи правління в Державі Ізраїль (1996-2003). Політичне життя. 2018. № 4. C. 37-43. DOI: 10.31558/2519-2949.2018.4.6.

5. Дунаева Е. Иран: изменение баланса политических сил после выборов Х. Роухани. Актуальные проблемы Ближнего и Среднего Востока. Москва : ДА МИД РФ. 2017. С. 17-30.

6. Дунаева Е. Политическая система Исламской Республики Иран: вызовы либеральной модернизации. Россия и мусульманский мир. 2016. № 9. С. 95-109.

7. Иваненко В. Иран: итоги правления М. Ахмадинежада и проблемы для нового президента. Проблемы национальной стратеаи. 2013. № 5 (20). С. 73-90.

8. Мамедова Н. Политическая система Исламской Республики Иран: особенности и возможности трансформации. Контуры әлобальных трансфоомаций: политика, экономика, право. 2018. Т. 11. № 3. С. 152-165. DOI: 10.23932/2542-0240-2018-11-3-152-165.

9. Мартыненко Н. Процесс политической модернизации Ирана. Свободная мысль. 2014. № 5 (1647). C. $73-86$.

10. Chehabi H.E., Schirazi A. The Islamic Republic of Iran. Journal of Persianate Studies. 2012. Vol. 5. № 2. P. 175-204. DOI: 10.1163/18747167-12341243.

11. Elgie R. A Fresh Look at Semipresidentialism: Variations on a Theme. Journal of Democracy. 2005. Vol. 16. № 3. P. 98-112.

12. Литвин В. Атрибути та різновиди напівпрезидентської системи правління в Європі: інституційно-процесуальний і політично-поведінковий аспекти : монографрія. Львів : Львівський національний університет імені Івана Франка, 2018. 636 с.

13. Литвин В., Романюк А. Концептуалізація і теоретична дистинкція понять «форма державного правління» та «система державного правління» у політичній науці. Науковий часопис Національного педагогічного університету імені М. П. Драгоманова. Серія 22 «Політичні науки та методика викладання соціальнополітичних дисциплін» : збірник наукових праць. Вип. 20. Київ : Вид-во НПУ імені М. П. Драгоманова, 2016. C. 3-12.

14. Shugart M., Carey J. Presidents and Assemblies. Constitutional Design and Electoral Dynamics. Cambridge : Cambridge University Press, 1992. 316 p.

15. Конституция Исламской Республики Иран 1979 г. (с изменениями от 1989 г.). URL: http://www.cis-emo.net/ sites/default/files/imagesimce/constitution_of_iran.pdf (дата обращения: 27.01.2020).

16. Iran (Islamic Republic of)'s Constitution of 1979 with Amendments through 1989. URL: https://www.constituteproject.org/constitution//ran_1989.pdf?lang=en (Last accessed: 27.01.2020).

17. Farhi F. Iran Inside and Out. Rocky Harbors: Taking stock of the Middle East in 2015: A Report of the CSIS Middle East Program. 2015. P. 47-55. URL: https://csis-prod.s3.amazonaws.com/s3fs-public/legacy_files/files/ publication/150408_Farhi_RockyHarbors_chapter6.pdf (Last accessed: 27.01.2020).

18. Сажин В. Корпус стражей исламской революции в Иране - государство в государстве. Контуры әлобальных трансформаций: политика, экономика, право. 2017. Т. 10. № 3. С. 83-109.

19. Цуканов В. Государственное экономическое регулирование в Иране: отход от исламских принципов? Ислам и общественное развитие в начале XXI века / отв. редакторы В.Я. Белокреницкий, А.З. Егорин, Н.Ю. Ульченко. Москва : Крафрт+, 2005. С. 424-431.

20. Филин Н. Социально-историческое развитие Исламской республики Иран (1979-2008 гг.): фракторы устойчивости государственной власти : дисс. ... канд. ист. наук. Москва : Российский государственный гуманитарный университет, 2009. 295 с.

21. Беккин Р. Исламская экономическая модель и современность. Москва : Издательский дом Марджани, 2009. $337 \mathrm{c}$.

22. Журавлев А. Принципы функционирования исламских банков. Исламские финансы в современном мире. Экономические и правовые аспекты / под ред. Р.И. Беккина. Москва : Ummah, 2004. С. 49-126.

23. Хатами М. Ислам, диалог и гражданское общество / пер. с англ. : В.Н. Трибунская и др. Москва : РОССПЭН, 2001. $237 \mathrm{c.}$

24. Мустафин А. Об итогах реформаторской деятельности в Иране. Ближний Восток и современность. Вып. 19. Москва : Институт изучения Израиля и Ближнего Востока, 2003. С. 172-179.

25. Samii W. Iran's 2000 elections. Middle East Review of International Affairs. 2000. Vol. 4. № 1. P. 1-15. 
26. Bakhash S. Reformists, Conservatives and Iran's Parliamentary Elections. Kechichian J.A. Iran, Iraq, and the Arab Gulf States. New York : Palgrave, 2001. P. 13-29.

27. Врадий А. «Третий путь» Ирана. Геополитика. RU. 06.08.2012. URL: https://www.geopolitica.ru/article/ tretiy-put-irana (дата обращения: 27.01.2020).

28. Абосзода Ф. Ахмадинежад против «стражей исламской революции» и кандидат США в Тегеране. Инфоормационное агентство REX. 19.01.2013. URL: http://www.iarex.ru/articles/33183.html (дата обращения: 27.01.2020).

29. Розов А. «Акции справедливости» - новая социальная инициатива М. Ахмадинежада. Институт Ближнего Востока. 2006. 30 октября. URL: http://www.iimes.ru/?p=5063 (дата обращения: 27.01.2020).

30. Кожанов Н. Социально-экономическая ситуация в Иране и государственная программа реформ. Институт Ближнего Востока. 2008. 27 июня. URL: http://www.iimes.ru/?p=7278 (дата обращения: 27.01.2020).

31. Филин Н. Неудавшаяся революция цвета ислама: причины подъема и упадка Зеленого движения в Иране. Москва : Ленанд, 2015. 320 с.

32. Президент Ирана: Главным принципом внешней политики Тегерана станет умеренность, но не подчинение и капитуляция. Арменпресс. 2013. 29 июня. URL: https://armenpress.am/rus/news/724507/prezidentirana-glavniym-principom-vneshneiy-politiki-tegerana.html (дата обращения: 27.01.2020).

33. Vahdat A. Iran to ban morality police from targeting women. The Telegraph. 2013. November 13. URL: https://www.telegraph.co.uk/news/worldnews/middleeast/iran/10446613//ran-to-ban-morality-police-from-targetingwomen.html (Last accessed: 27.01.2020).

34. Rouhani $\mathrm{H}$. If we want domestic security we must give everyone equal opportunity. Women too must have the same opportunity as men 1/2. Twitter. 2013. August 20. URL: https://twitter.com/HassanRouhani/ status/369799969152049152 (Last accessed: 27.01.2020).

35. Iran: Political Opposition Groups, Security Forces, Selected Human Rights Issues, Rule of Law: COI Compilation. Austrian Centre for Country of Origin and Asylum Research and Documentation (ACCORD). 2015. URL: https://www.refworld.org/docid/559baae44.html (Last accessed: 27.01.2020). 